\title{
Auxiliarul de perfect compus o din graiul moldovenesc. Diacronie şi sincronie
}

\author{
Mădălina Botez ${ }^{1 *}$, Adina Dragomirescu ${ }^{1,2,3 *}$ \\ ${ }^{1}$ Facultatea de Litere, Universitatea din București, Str. Edgar Quinet 5-7, 010017 București, România \\ ${ }^{2}$ Institutul de Lingvistică „Iorgu Iordan - Al. Rosetti”, Calea 13 Septembrie 13, 050711 București, România \\ ${ }^{3}$ Institutul de Cercetări al Universității din București, Bd. Mihail Kogălniceanu 36-46, 050107, București, România
}

\section{Despre articol}

Istoric:

Primit 3 mai 2017

Acceptat 13 mai 2017

Publicat 30 septembrie 2017

Cuvinte-cheie:

grai moldovenesc

auxiliar

perfect compus

asimilare

cliticizare

\begin{abstract}
Rezumat
Scopul acestui articol este acela de a analiza auxiliarul de perfect compus $o$ din graiul moldovenesc. Analiza este precedată de o discuție despre originea, datarea, localizarea și evoluția formei $o$ în limba română pînă în secolul al XIXlea. Deși conform bibliografiei și atlaselor lingvistice, forma $o$ este generală în Moldova, studiul nostru de corpus va arăta că alături de forma $o$ se folosesc, sub influența limbii standard, și formele $a$ și $a u$, și că există o tendință de specializare a formei $o$ pentru contextele cu cliticizare multiplă.

Analiza noastră — care contribuie la înțelegerea interfeței fonologie-morfologie—poate fi extinsă la studiul altor varietăți teritoriale ale românei.
\end{abstract}

\section{Introducere}

În acest articol analizăm auxiliarul de perfect compus $o$ (persoana a III-a singular și plural) din graiul moldovenesc. Cercetarea noastră pornește de la observația că informațiile despre această formă incluse în tratatele de dialectologie și în atlasele lingvistice sînt destul de diferite de cele din texte: dacă tratatele spun destul de tranșant că forma $o$ se folosește în Moldova la persoana a III-a atît la singular, cît și la plural, lucru confirmat în mare măsură de hărțile din atlasele lingvistice, situația din texte este destul de diferită: alături de forma $o$, se folosesc adesea formele literare standard $a$ și au (sincretic, pentru singular și plural). În continuare, vom încerca să aflăm care sînt factorii care influențează folosirea formei $o$ sau a formelor a/au în graiul moldovenesc. Cercetarea poate fi extinsă și la alte graiuri care au forme duble ale auxiliarului.

Mai întîi, vom trece în revistă informațiile din bibliografie despre distribuția formei $o$ în graiurile dacoromâne și ipotezele despre originea formei $o(\$ 2)$. După aceea, vom urmări istoria formei $o$ de la primele sale atestări și pînă în secolul al XIX-lea (\$3). În fine, vom analiza distribuția formei $o$ şi a formelor paralele a/au în cîteva hărți din atlasele lingvistice și în texte dialectale moldovenești ( $\$ 4$ ). În $\$ 5$, vom formula concluziile, precum și o explicație pentru utilizarea în paralel a celor două forme ale auxiliarului.

\section{Auxiliarul $o$ în graiurile dacoromâne}

În această secțiune, prezentăm distribuția formei $o$ în graiurile actuale, așa cum reiese din lucrările de dialectologie, și ipotezele privind originea acestei forme.

\subsection{Distribuția formei $\boldsymbol{o}$ in graiurile actuale}

Conform lucrărilor de dialectologie, una dintre trăsăturile care disting graiurile de sud de cele de nord este forma auxiliarului de perfect compus, pentru persoana a treia: $a$ în Muntenia și $o$ în graiurile de nord, atît la persoana a III-a singular, cît și la persoana a III-a plural.

*Adrese de corespondență: madalynabotez@yahoo.com (MB), adina_drag@yahoo.com(AD). 
În tabelul de mai jos, am sintetizat informația din Caragiu Marioțeanu et al. (1977, p. 142, 149, 158, 162, 167) și TDR (1984, p. 179, 225, 263, 309, 337), pentru a crea o imagine sintetică asupra formei de persoana a III-a a auxiliarului de perfect compus pe întreg teritoriul pe care se vorbește dacoromâna.

\begin{tabular}{lcc} 
Subdialectul & Persoana a III-a singular & Persoana a III-a plural \\
\hline muntenesc & $a$ & $a$, au \\
moldovenesc & $\boldsymbol{o}$ & $\boldsymbol{o}$, au \\
bănățean & $\boldsymbol{o}$ & or \\
crișean & $\boldsymbol{o}$ & $\boldsymbol{o}$, or, au \\
maramureșean & $\boldsymbol{o}$ & $\boldsymbol{o}$, or \\
graiurile din Transilvania & $\boldsymbol{o}$ & $\boldsymbol{o}$, or
\end{tabular}

Tabela 1: Distribuția auxiliarului $o$ în graiurile dacoromâne

Din tabelul de mai sus se poate observa că, potrivit tratatelor de dialectologie, forma de care ne ocupăm, $o$, apare în graiurile nordice atît la singular, cît și la plural, cu excepția Banatului, unde este specifică numai singularului. Dintre graiurile de nord, cel moldovenesc se individualizează prin absența formei de plural $o r$, forma $o$ fiind deci folosită sincretic, atît pentru singular, cît și pentru plural.

\subsection{Ipoteze despre originea formei $\boldsymbol{o}$}

Așa cum vom arăta pe larg în $\$ 3$, forma $o$ nu era atestată în prima perioadă a limbii române vechi. Așadar, forma $o$ a apărut mai tîrziu, iar originea ei este controversată. La Frâncu (1969, p. 303) apare o sinteză despre ipotezele legate de apariția formei $o$ :

(i) forma $o$ a înlocuit forma $a$ în condiții specifice (Coteanu, 1961, p. 89): mai întîi, a apărut forma de persoana a III-a plural or (extinsă de la auxiliarul de viitor a vrea, prin intermediul viitorului anterior cu valoare de prezumtiv, care este tot un timp trecut), iar apoi s-a refăcut și forma de singular $o$; pentru graiul de care ne ocupăm aici, această ipoteză este greu de susținut, deoarece în Moldova nu se folosește deloc or pentru plural;

(ii) $o<a u(<$ HABUNT), prin asimilare, ipoteză susținută de Frâncu (1969, p. 303), cu date din româna veche (vezi §3);

(iii) $o$ are o dublă origine: a avea și $a$ vrea.

Așa cum observă și Coteanu (1961, p. 89), și Frâncu (1969, p. 303), forma $o$ nu se poate explica prin $a$, pentru că o astfel de evoluție fonetică este imposibilă în română. Frâncu (1969, p. 305-306) argumentează împotriva ipotezelor (i) și (iii), arătînd că ariile lui $o$ de la perfect compus și ale lui $o$ de la viitor sînt complet diferite, viitorul cu $o$ este mai recent decît perfectul compus cu $o$, iar forma or (prezentă numai în Banat, conform acestui autor) datează de la începutul secolului al XIX-lea; aşadar, forma $o$ de la perfectul compus este probabil anterioară contaminării între a vrea și a avea, petrecută recent în Banat.

După ce vom analiza, în secțiunea următoare, datele oferite de româna veche, vom adera și noi la ipoteza că $o$ provine din $a u$.

\section{Auxiliarul $o$ în diacronie}

Problema auxiliarului $o$ pentru persoana a III-a a perfectului compus nu a atras prea mult atenția cercetătorilor. S-au ocupat de acest subiect Frâncu (1969), Gheție (1975) și Zamfir (2007), autori care au ajuns la rezultate uneori diferite, deoarece corpusul de texte pe care se întemeiază concluziile lor este diferit.

3.1. Frâncu (1969, p. 304) arată că forma $o$ este destul de veche, apărînd în documente nordice de la începutul secolului al XVII-lea. Conform cercetărilor sale, forma $o$ este absentă nu numai din textele religioase (ceea ce arată că era în afara normei), ci și din documentele muntenești. Este atestată o singură dată în cel mai vechi manuscris al Alexandriei, din 1620 (1). Tot Frâncu (1969, p. 304) observă că forma $o$ nu apare la cronicarii munteni, deoarece copiile care ne-au parvenit au fost făcute de copiști munteni. 
(1) ți-o dat (A.1620, 112/13).

Pentru a-și susține ipoteza despre originea formei $o$ (vezi supra, \$2.2), Frâncu (1969, p. 300-304) analizează și distribuția formelor $a$ și au în româna veche. Autorul observă că, în secolul al XVI-lea, forma $a$ nu apare în textele rotacizante și în tipăriturile lui Coresi (care cunosc exclusiv forma au pentru persoana a III-a singular și plural), primul text religios în care este atestată fiind Po.1582. Frâncu (1969, p. 301) arată că $a$ nu este o simplă greșeală de scriere, ci ilustrează, mai degrabă, pătrunderea involuntară și inconștientă a unor elemente de oralitate în limba scrisă. Așadar, forma $a$ nu aparține normei lingvistice a secolului al XVI-lea, dar este probabil că era folosită în vorbire. În secolul al XVII-lea, a este întrebuințat frecvent în Muntenia (Frâncu, 1969, p. 302). În secolul al XVII-lea, existau deci două arii pentru persoana a III-a singular a auxiliarului de perfect compus: o arie sudică, unde se foloseau $a$ și $a u$, și o arie nordică, unde se foloseau $o$ și $a u$.

Frâncu (1969, p. 304) arată că faza iniţială a asimilării lui $a$ din $a u$ de către labiala $u$ este atestată în inscripții din Maramureș, datînd din prima jumătate a secolului al XVII-lea:

(2) Popa Pinte nu oo dat ce oou plătit și oou spus (Iм, p. 33, apud Frâncu, 1969, p. 302).

Frâncu (1969, p. 304) observă că transformarea au > o prin asimilare apare mai ales cînd auxiliarul e precedat de o vocală labială, în cele mai multe cazuri de $o$ complement direct, care este antepus verbului în româna veche, și ilustrează această situație cu exemple de tipul:

(3) a. Această carte $\boldsymbol{o - u}[=$ o au] cumperat popa Lupu (1720, MM, IM, p. 33)

b. Cum o- $\boldsymbol{u}[=$ o au $]$ crescut $(1619, \mathrm{DR}, 45)$

c. Cum au luat pre Despina de mică de $\boldsymbol{o}$ [= o au] ținut el și $\boldsymbol{o}$ crescut el ca of fată a lui și $\boldsymbol{o}$ hrănit 30 de ani (1615, Mold, DB, 111)

Frâncu (1969, p. 305) ajunge la concluzia că forma $o$ provine din $a u$, iar grafiile $o-u, o o$ reprezintă faza inițială a asimilării lui $a$ din $a u$, în context cu o vocală labială. Un argument suplimentar pentru a susţine această concluzie este că $o$ apare în limba veche numai în ariile în care se folosesc exclusiv forme cu au pentru ambele numere, iar azi, au se întîlnește numai în ariile cu $o$.

3.2. Gheție (1975, p. 171) arată că în Moldova forma nouă $o$ apare curînd după 1600 (4). În Transilvania, $o$ este atestat la începutul secolului al XVII-lea și apare frecvent în documente după 1700. În Banat, de unde nu avem documente dinainte de secolul al XVIII-lea, $o$ a fost înregistrat o singură dată (5).

(4) a. o crescut (1615)

b. o dat (1619)

c. $\operatorname{s-opus}(1660)$

d. o ținut (1699)

(5) o cumpărat-o (1732)

3.3. Și Zamfir (2007, p. 111) propune aceeași datare: forma $o$ este o inovație a secolului al XVII-lea, neatestată în secolul al XVI-lea. Lucrînd pe un corpus mai mare de texte, mai ales de documente, recent editate, Zamfir (2007, p. 112) ajunge la rezultate mai nuanțate decît predecesorii săi: în limba română veche, forma $o$ avea o distribuție inversă față de cea de astăzi: în prima perioadă din limba română veche, autoarea identifică 12 ocurențe în documentele din Țara Românească (nemenționate de Frâncu) și două ocurențe în Moldova.

Zamfir (2007, p. 111) arată că faza inițială despre care vorbește Frâncu (1969), ilustrînd-o cu exemple din inscripții maramureșene, este atestată destul de frecvent și în documentele din sud. Autoarea citează exemple în care auxiliarul au precedat de pronumele aton $o$ apare „redus” la $u$ semivocalic prin eliziune: 
(6) a. o-u vindut (DRH A XIX/361, 505, 1; DRH A XXI/132, 169, 12) - $3 \mathrm{pl}$

b. o-u cumpărat (DIR A II/347, 266, 4) - 3 pl

Semnificativ pentru analiză este faptul că din cele 15 ocurențe ale auxiliarului $o$, identificate de Zamfir (2007), în 12 acest element apare în contexte în care prezența pronumelui aton $o$ este cerută sintacticașadar, verbele sînt tranzitive - (7) —, dar în care, spre deosebire de exemplele de la (6), nu există rudimente ale formei originare a auxiliarului.

(7) $o[<o o]$ datu, $o[<o o]$ vîndut, $o[<o o]$ ținut, $o[<o o]$ criscut, $o[<o o]$ hrănit, fostu-o $[<o o]$ luat, $o[<o o]$ fost dat, $o[<o o]$ fost vîndut, $o[<o o]$ văndut

Așadar, formele cu $o$ din contextele în care ar fi de așteptat succesiunea $o$ au reprezintă un pas înainte față de formele cu eliziune (Zamfir, 2007, p. 113). În plus, eliziunea afectează și alte persoane ale auxiliarului (8), aşadar, nu există o legătură necesară între eliziune și constituirea unei variante sistematice $o$ la persoana a III-a a perfectului compus.

(8) o-mu vindutu

Concluzia autoarei este că $o$ din documentele muntenești este un pseudoauxiliar, care încorporează deci două elemente: cliticul $o$ și auxiliarul de persoana a III-a $o$.

Zamfir (2007, p. 113) are o contribuție însemnată și la datarea și localizarea originară a formei de plural or $(u)$, specifică azi Banatului, pe care o înregistrează pentru prima oară tot într-un document din Țara Românească (9), sugerînd însă că probabil scribul era din Banat.

(9) oru facut (DRH B XXIII/436, 636, 8, 1632)

O ultimă observație de reținut este că structura fonetică a auxiliarului de perfect compus din limba veche, pentru toate persoanele, este, în multe cazuri, alterată ca urmare a aglutinării cu alte forme monosilabice, în special pronume atone. Așadar, corpul fonetic al auxiliarului suferă de o „vulnerabilitate” accentuată (Zamfir, 2007, p. 114).

3.4. O investigație a situației din secolul al XIX-lea (Dragomirescu, 2012, p. 204) arată că și în această perioadă forma $o$ era în afara normei. Pînă în 1880, în Moldova, forma au este cvasigenerală, dar unele gramatici menționează și formele $a$ și $o$. Chiar dacă gramaticile nu o recomandă, forma $o$ apare, rar însă, la scriitori moldoveni:

(10) a. s-o fudulit, te-o apucat (Alecsandri)

b. s-o-ntîlnit (Conachi).

3.5. Așadar, există un consens în bibliografie în privința faptului că forma $o$ a auxiliarului de perfect compus a apărut la începutul secolului al XVII-lea. Informația diacronică sugerează că nu poate exista o relație directă între auxiliarul de viitor și formele $o$, or ale auxiliarului de perfect compus. Un alt punct comun pare a fi relaţia dintre auxiliarul $o$ și cliticul pronominal $o$, eventual și alte clitice pronominale.

În ceea ce privește originea acestei inovații, informațiile sînt diferite: Frâncu (1969) identifică forme cu $o$ numai în documente din Moldova și formele hibride (de tipul oo sau $o=$ auxiliar + clitic) în inscripții din Maramureș, în timp ce Zamfir (2007) descoperă atît forma $o$ (auxiliar sau clitic + auxiliar), cît şi forme hibride $(o-u)$ mai ales în Muntenia. Pentru scopul prezentei analize, vom adera și noi la ipoteza că $o$ provine din au, prin asimilare, condițiile fonetice fiind respectate: vocala /a/, care este [centrală, deschisă, nerotunjită] este asimilată parțial de vocala /u/, care este [posterioară, închisă, rotunjită], rezultînd vocala /o/, care este [posterioară, semideschisă, rotunjită], așadar păstrîndu-se toate trăsăturile lui /u/, cu excepția celei de apertură, care se modifică sub influența vocalei deschise /a/. 
De asemenea, reținem ideea că auxiliarul de perfect compus era, în limba veche, indepedent de regiune, extrem de vulnerabil din punct de vedere fonetic.

În secțiunea următoare, vom analiza distribuția auxiliarului $o$ în graiul moldovenesc, mai întîi în atlase, apoi în texte, urmărind dacă există restricții legate de clasa de verbe (dacă auxiliarul $o$ este preferat în contexte tranzitive, în care este posibilă și apariția cliticului $o$ ) și de prezența altor elemente clitice.

\section{Auxiliarul $o$ în graiul moldovenesc. Relaţia cu cliticizarea}

Spre deosebire de alte graiuri nordice, în Moldova, auxiliarul $o$ este folosit și pentru singular, și pentru plural, neexistînd o formă specială de plural, de tipul or, ca în alte zone.

\subsection{Datele din atlasele lingvistice}

În această secțiune, analizăm cîteva hărți din ALR s.n. V și VI și din ALR I care cuprind contexte cu forme de perfect compus la persoana a III-a (toate la singular), însoțite de clitice, pentru a vedea ce forme se preferă în zona Moldovei.

(i) Pe harta 1625, (Calul) mi l-a dat tata (ALR s.n. VI), apare de 11 ori forma $o$ și de două ori forma $a$.

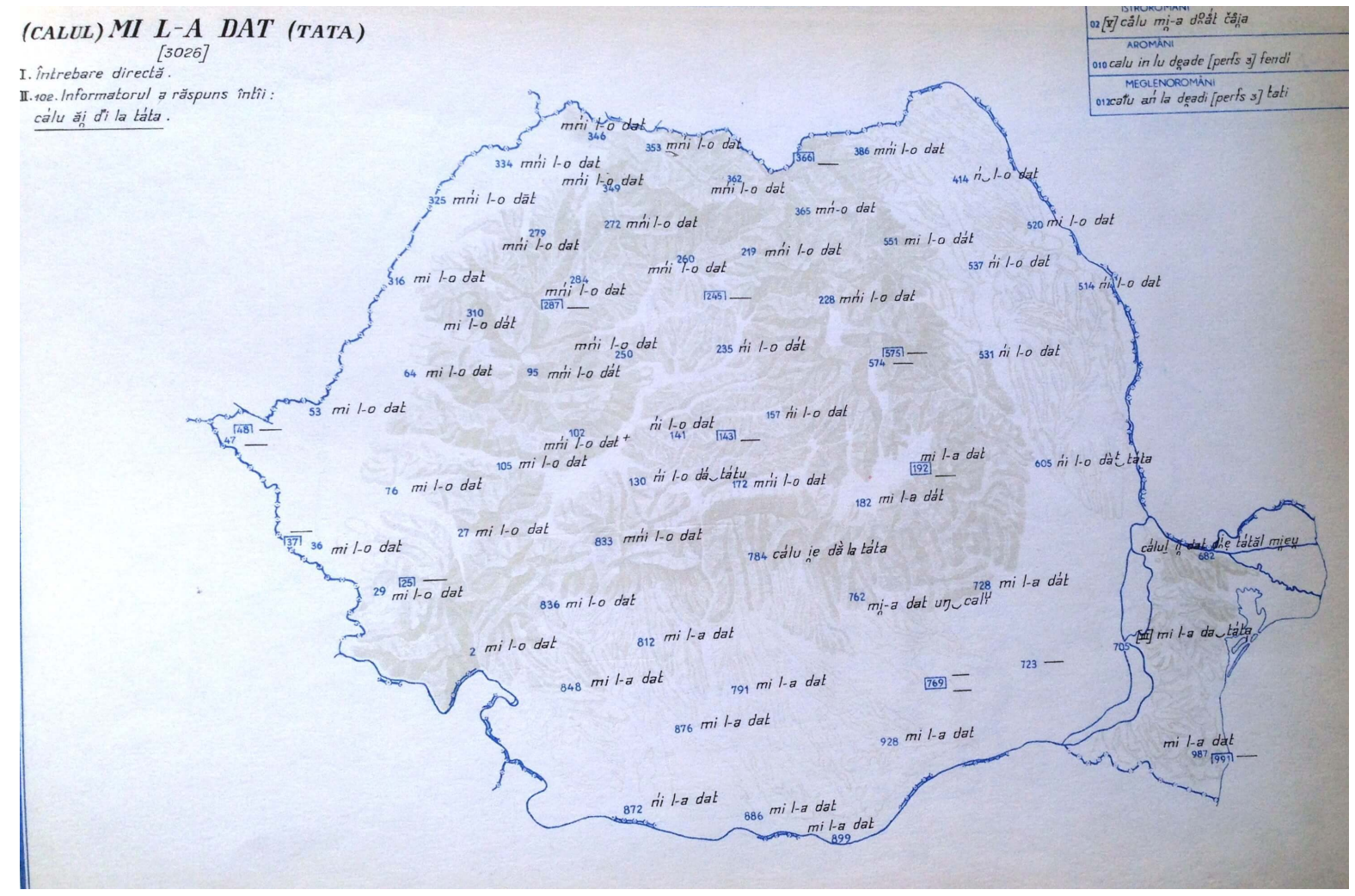

(ii) Pe harta 1630, Cine ți-a dat plăcintă (ALR s.n. VI), forma $o$ este folosită în nouă puncte, iar forma $a$, în două puncte: 


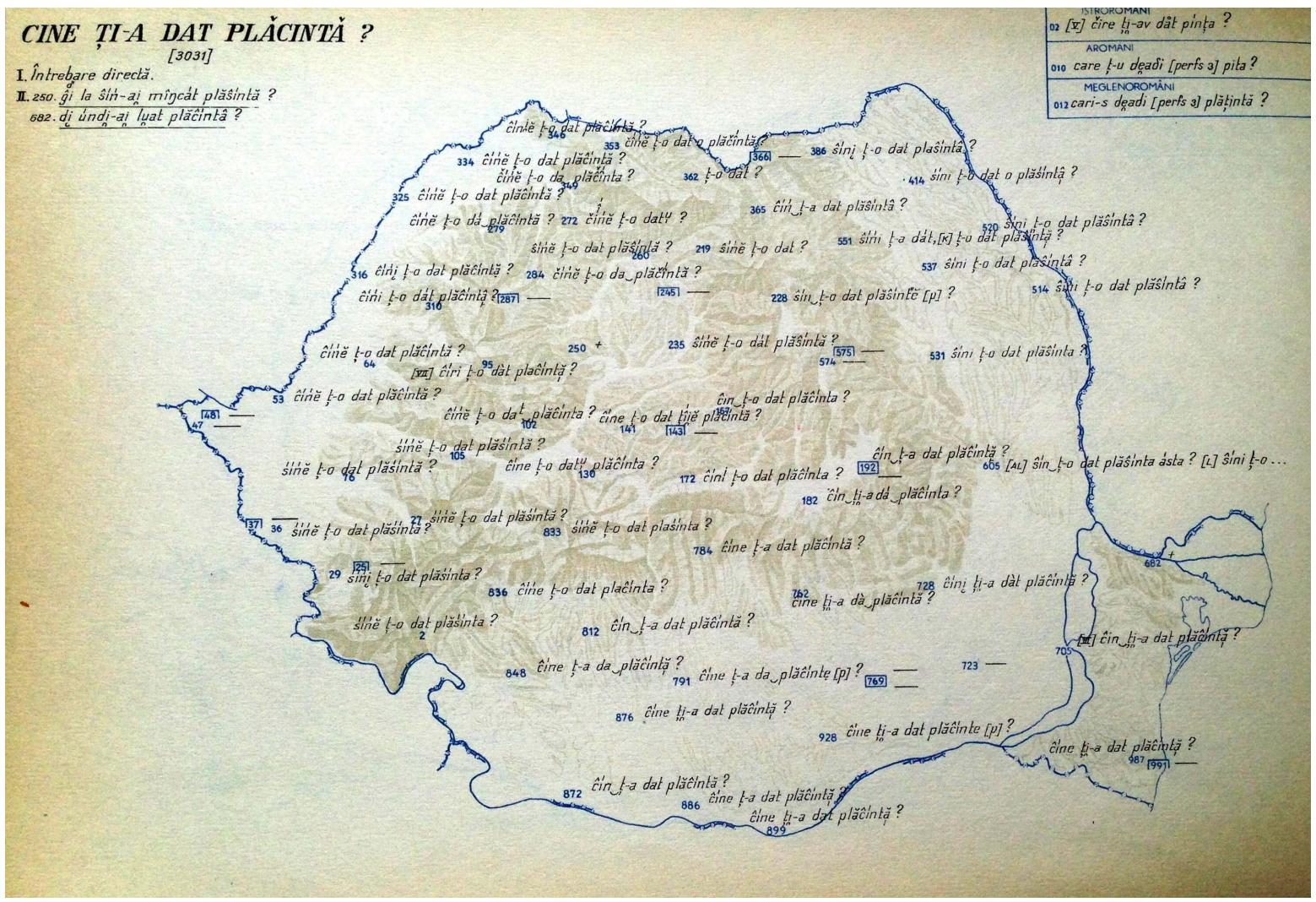

(iii) Pe harta 1642, Pe noi ne-a văzut tata (ALR s.n. VI), apare $o$ de opt ori, iar $a$ de două ori:

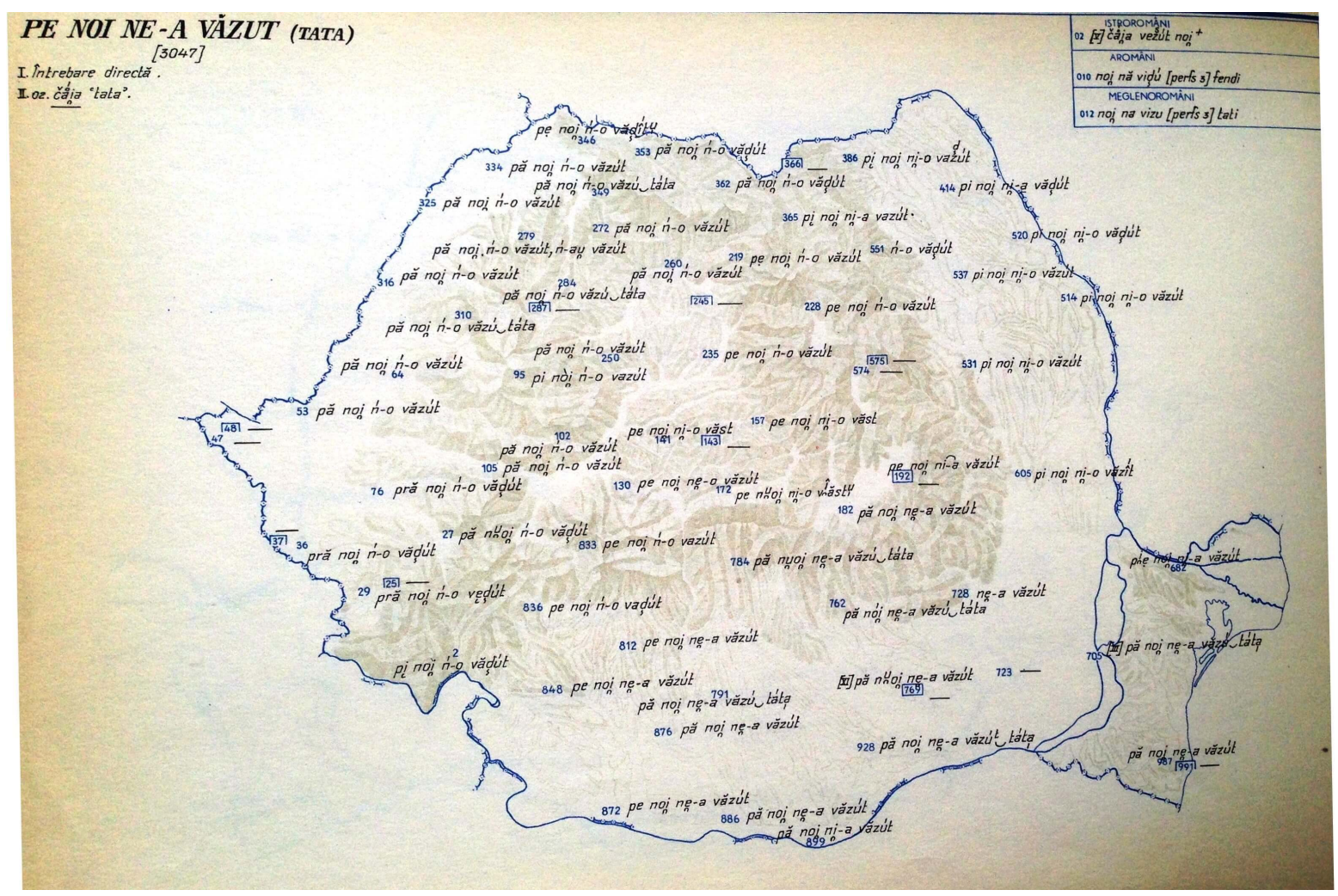

(iv) Pe harta 1455, S-a mînjit (cu funingine pe față) (ALR s.n. V), în nouă puncte este folosită forma $o$, iar în două, forma $a$ : 


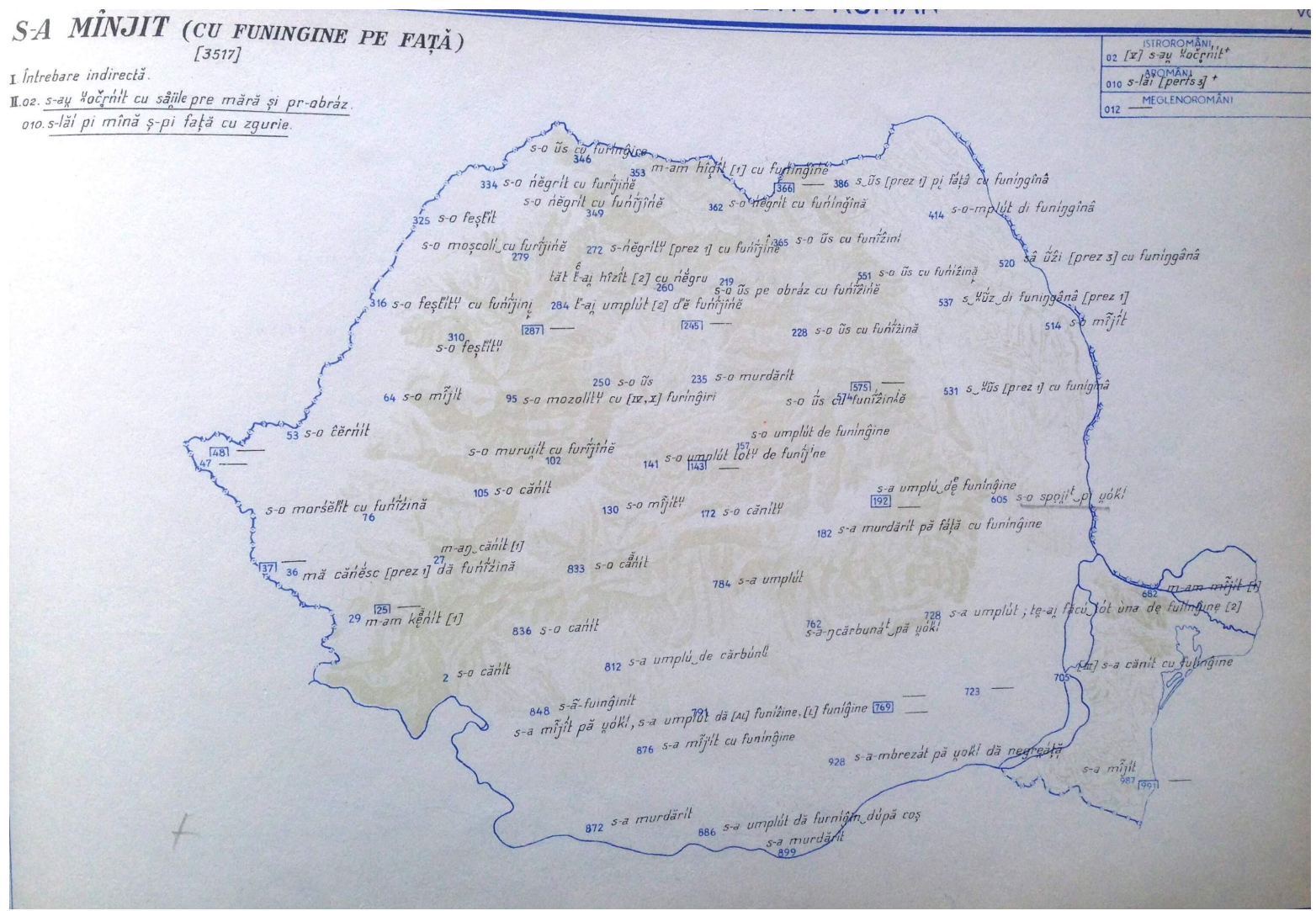

(v) Pe harta 1706, ... I-a murit bărbatul (ALR s.n. VI), apar opt structuri cu $o$ şi două cu $a$ :

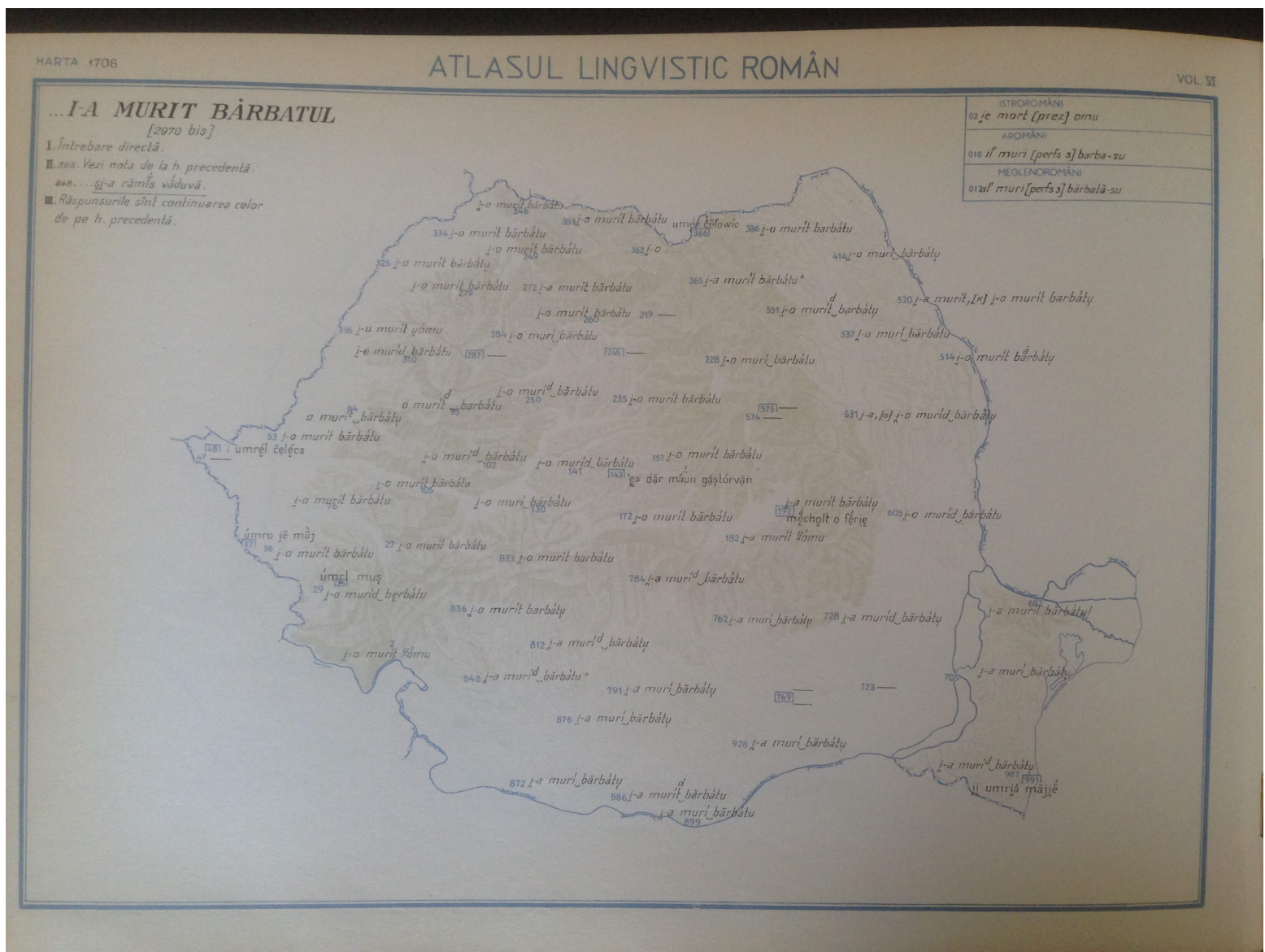

(vi) Pe harta 302, Așa mi-a fost soarta (ALR I, vol. II, partea II) în 49 de puncte se folosește $o$, iar în 12 puncte, $a$ : 


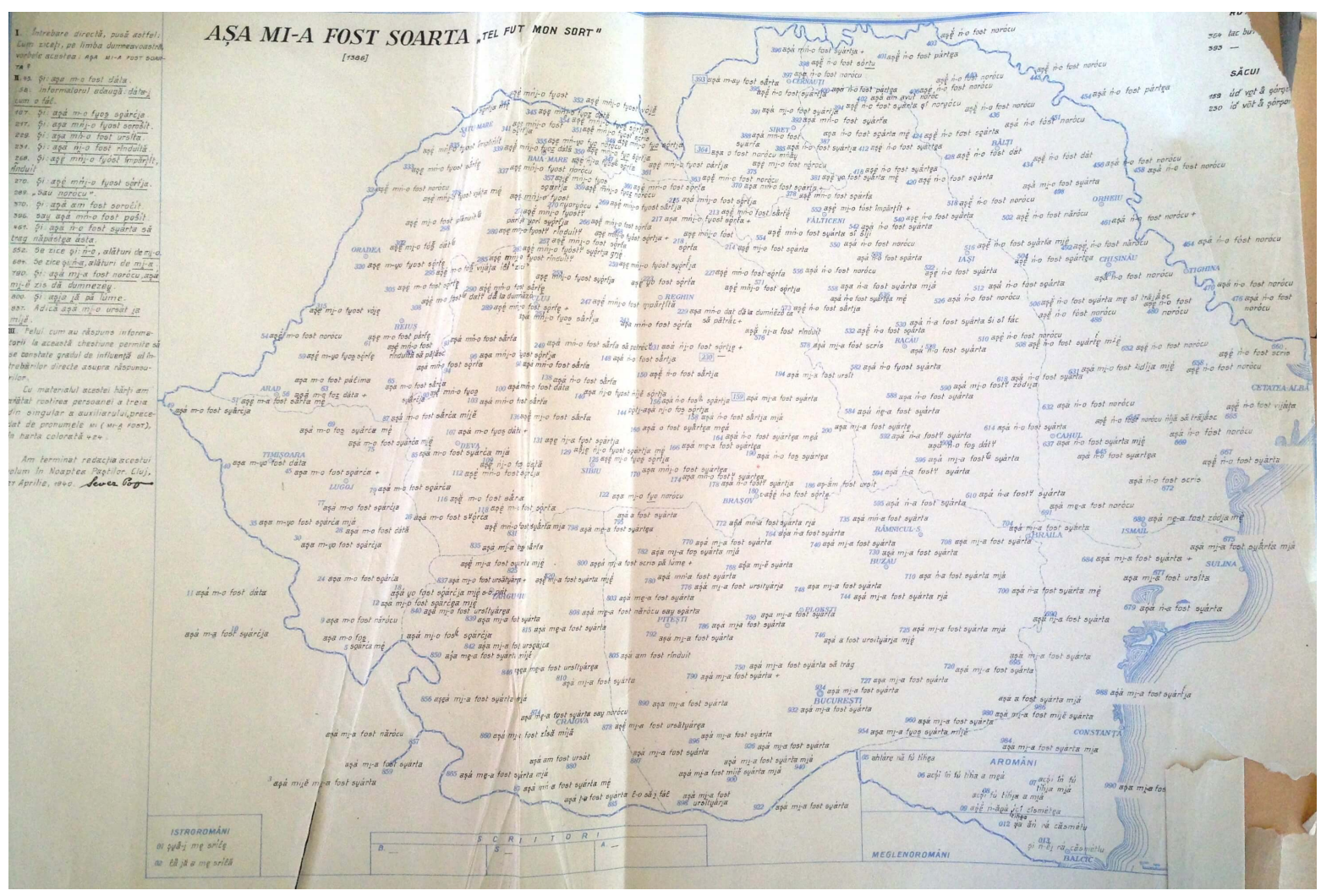

Din analiza acestor hărți reiese că $o$ se preferă în toată zona Moldovei, mai puțin în cîteva puncte din sud, unde apare forma $a$. Rezultatele analizei hărților arată că $o$ este compatibil atît cu verbe tranzitive [(i)(iv)], cît și cu verbe intranzitive [(v) -(vi)] și nu sînt foarte relevante pentru relația cu cliticizarea, deoarece același lucru se observă și în situațiile în care auxiliarul nu este însoțit de alte elemente clitice (de exemplu, pe hărțile Atîția au venit, A făcut ce-a făcut și Au ars din ALR s.n.). Așadar, conform atlaselor, forma $o$ este generală în Moldova (cu excepția punctelor din sud), indiferent dacă este însoțită sau nu de alte clitice. Situația din atlase confirmă deci, în linii mari, descrierea din tratatele de dialectologie.

\subsection{Datele din texte}

Textele analizate pentru această lucrare au fost grupate în trei categorii (vezi și Botez, 2016), care ilustrează atît vechimea diferită a textelor, cît şi repartizarea teritorială:

(i) înregistrări mai vechi (din perioada 1930-1960), de pe întreg teritoriul care corespunde graiului moldovenesc, incluse în volumul de texte dialectale publicat de Emil Petrovici ca supliment la ALR II (siglate mai jos ca TD) și în Caragiu Marioțeanu et al. (1977) (siglate mai jos ca DR);

(ii) textele dialectale (din perioada 1968-1972) incluse în suplimentul la NALR, volumul I, partea a II-a (județele Vrancea, Galați și Bacău), publicat de Stelian Dumistrăcel în 1995;

(iii) înregistrări făcute de Mădălina Botez în 2016 în două sate din județul Neamț (Grințieșu Mare și Poiana, ambele din comuna Grințieș) și în Tîrgu Neamț.

În privința relației dintre auxiliarul $o$ și tranzitivitatea verbului cu care se combină (vezi mai sus discuția de la Zamfir, 2007), trebuie precizat că în textele analizate auxiliarul $o$ este compatibil deopotrivă cu verbe tranzitive (11) și intranzitive (12).
a. $\operatorname{odat}(\mathrm{TD}, 166)$
b. o văzutî (TD, 197)
c. ofäcut $(\mathrm{TD}, 202)$
a. $\operatorname{ovinit}(\mathrm{TD}, 166,180,201,208)$
b. $\quad$ stat $(\mathrm{DR}, 236)$ 
c. oplecat $(\mathrm{DR}, 236)$

În texte dialectale din categoria (i), au fost identificate 31 de structuri cu $o$ neînsoțit de alte clitice, 23 la singular (13a) și 8 la plural (13b). În 60 de contexte, $o$ este însoțit de clitice pronominale și de conjuncții coordonatoare și subordonatoare, 52 la singular $(14 a-c)$ și 8 la plural $(14 d)$. Forma literară $a$ nu este înregistrată în aceste texte, iar au apare o dată pentru singular (15a) și o dată pentru plural (15b).

(13) a. o ieşît (TD, 197, 205)

b. o trecut (DR, 236)

(14) a. l-o-ntrebat (TD, 179)

b. ş-o dus-o (TD, 180)

c. $c$-o vădut (TD, 212)

d. s-o facut (TD, 169)

a. au gîcit $(\mathrm{TD}, 171)$

b. au pălit (TD, 172)

În textele din categoria (ii), au fost identificate 19 contexte cu forma $o$ neînsoțită de alte elemente clitice (16) și 71 de contexte cu $o$ insoțit de clitice pronominale și de conjuncții coordonatoare și subordonatoare (17). Formele $a$ (pentru singular și plural) și au (pentru plural) apar neînsoțite de alte elemente clitice în 135 de contexte (18) și însoțite de clitice în 196 de contexte (19).

(16) a. o intrat (NALR, 15)

b. o vinit (NALR, 15)

(17) a. m-o lovit un minz (NALR, 15)

b. c-o fost (NALR, 21)

(18) a. a sărit cu toțî (NALR, 23)

b. a liegat vaca (NALR, 12)

(19) a. m-a trimespărințî (NALR, 238)

b. s-audus (NALR, 12)

În textele din categoria (iii), au fost identificate 25 de construcții cu $o$ neînsoțit de alte elemente clitice, 22 la singular (20a) și 3 la plural (20b) și 31 de construcții cu $o$ însoțit de clitice pronominale și de conjuncții coordonatoare și subordonatoare, de pronume relative, 24 la singular $(21 \mathrm{a}-\mathrm{c})$ și 7 la plural $(21 \mathrm{~d}-\mathrm{e})$. Au fost identificate și cinci forme literare, toate la plural, dintre care patru fără alte elemente clitice (22) și una în care au se atașează relativului ce (în rostirea moldovenească $\left[\int \mathrm{e}\right](23)$.

(20) a. ofost

b. ovint

a. m-o ajutat

b. ş-o zîs

c. c-o fost

d. nu prea s-o dus

e. cari-o fost

a. aufaccut

b. au fost

c. au vrut

(23) ş-au faccut

În Tabela 2, sintetizăm rezultatele studiului de corpus; rezultatele importante pentru ipoteza noastră sînt date cu bold. 


\begin{tabular}{|c|c|c|c|c|c|}
\hline Sursa & $\begin{array}{l}o \text { [+ clitice, } \\
\text { conjuncții] }\end{array}$ & $\begin{array}{l}o \text { [- clitice, } \\
\text { conjuncții] }\end{array}$ & $\begin{array}{c}a, a u[+ \text { clitice, } \\
\text { conjuncții }]\end{array}$ & $\begin{array}{c}a, a u[- \text { clitice, } \\
\text { conjuncții] }\end{array}$ & Total \\
\hline $\begin{array}{l}\text { DR, TD } \\
(1930-1960)\end{array}$ & $\begin{array}{c}60 \\
(64,52 \%)\end{array}$ & $\begin{array}{c}31 \\
(33,33 \%)\end{array}$ & - & $\begin{array}{c}2 \\
(2,15 \%)\end{array}$ & $\begin{array}{c}93 \\
(100 \%)\end{array}$ \\
\hline $\begin{array}{l}\text { NALR (total) } \\
(1968-1972)\end{array}$ & $\begin{array}{c}71 \\
(16,86 \%)\end{array}$ & $\begin{array}{c}19 \\
(4,51 \%)\end{array}$ & $\begin{array}{c}196 \\
(46,56 \%)\end{array}$ & $\begin{array}{c}135 \\
(32,07 \%)\end{array}$ & $\begin{array}{c}421 \\
(100 \%)\end{array}$ \\
\hline a. Vrancea & $\begin{array}{c}33 \\
(13,63 \%)\end{array}$ & $\begin{array}{c}8 \\
(3,30 \%)\end{array}$ & $\begin{array}{c}126 \\
(52,07 \%)\end{array}$ & $\begin{array}{c}75 \\
(31 \%)\end{array}$ & $\begin{array}{c}242 \\
(100 \%)\end{array}$ \\
\hline b. Galați & $\begin{array}{c}17 \\
(48,58 \%)\end{array}$ & $\begin{array}{c}3 \\
(8,57 \%)\end{array}$ & $\begin{array}{c}11 \\
(31,42 \%)\end{array}$ & $\begin{array}{c}4 \\
(11,43 \%)\end{array}$ & $\begin{array}{c}35 \\
(100 \%)\end{array}$ \\
\hline c. Bacău & $\begin{array}{c}21 \\
(14,58 \%)\end{array}$ & $\begin{array}{c}8 \\
(5,56 \%)\end{array}$ & $\begin{array}{c}59 \\
(40,97 \%)\end{array}$ & $\begin{array}{c}56 \\
(38,89 \%) \\
\end{array}$ & $\begin{array}{c}144 \\
(100 \%)\end{array}$ \\
\hline $\begin{array}{l}\text { Înregistrări } \\
\text { (Neamț, 2016) }\end{array}$ & $\begin{array}{c}31 \\
(50,82 \%)\end{array}$ & $\begin{array}{c}25 \\
(40,98 \%)\end{array}$ & $\begin{array}{c}1 \\
(1,64 \%)\end{array}$ & $\begin{array}{c}4 \\
(6,56 \%)\end{array}$ & $\begin{array}{c}61 \\
(100 \%)\end{array}$ \\
\hline
\end{tabular}

Tabela 2: Distribuția formelor $o$ vs $a$, au în texte din Moldova

Datele statistice din tabel, deși nu sînt unitare, sugerează că: (i) textele din prima categorie, înregistrate în prima jumătate a secolului al XX-lea, confirmă în mare măsură informaţia din tratatele de dialectologie și din atlasele lingvistice, conform căreia forma $o$ este generală în Moldova; în textele din a doua categorie, culese în a doua jumătate a secolului al XX-lea în regiunea de sud a Moldovei, procentele sînt inegale: formele literare sînt preferate în textele din Vrancea și Bacău, pe cînd textele din Galați manifestă o preferință pentru forma $o$, mai ales atunci cînd este coocurentă cu alte clitice; din textele din ultima categorie, culese dintr-o zonă mai nordică, reiese clar preferința pentru forma $o$ a auxiliarului, indiferent de existența altor elemente clitice.

\section{Concluzii}

În urma analizei sincronice și diacronice a auxiliarului de perfect compus $o$ în graiurile din Moldova, am ajuns la următoarele concluzii:

(i) auxiliarul $o$ provine din $a u$, prin asimilare, iar contextul care a favorizat această transformare presupune existența altor clitice, în special a cliticului pronominal $o$-vezi exemplele (1)-(3), (4c-d), (5)-(7);

(ii) auxiliarul $o$ este atestat pentru prima dată la începutul secolului al XVII-lea; ca şi astăzi, a fost tot timpul în afara normei literare ${ }^{1}$, aparținînd deci registrului oral;

(iii) datele din tratatele de dialectologie și din atlasele lingvistice, precum şi textele din DR și TD, sugerează că forma $o$ este (cvasi)generală în Moldova;

(iv) datele din alte texte, culese ceva mai recent, unele foarte recent, sugerează, pe de o parte, că forma $o$ se folosește în paralel cu formele literare $a$, au (probabil sub presiunea limbii standard, mai ales în zona de sud a Moldovei), în contexte similare, și, pe de altă parte, că există o tendință incipientă de specializare a formei $o$ pentru contextele cu cliticizare fonologică multiplă.

Dincolo de aceste concluzii descriptive, putem formula ipoteza că situaţia actuală din graiul moldovenesc este determinată de contactul cu limba standard, un tip special de contact lingvistic, care presupune competiție (în acest caz, între forma $o$ și formele a/au) și schimbare (Van Coetsem, 1992, p. 27). Transferul de la varianta-sursă (limba standard) la varianta-țintă (graiul moldovenesc) presupune un proces de supradiferențiere (engl. over-differentiation, care se opune subdiferențierii, engl. under-differentiation -

\footnotetext{
${ }^{1}$ Pentru a verifica o dată în plus utilizarea auxiliarului $o$ în texte literare, am parcurs integral două texte vechi localizate în Moldova, Prav.1581 și șT.1644. Forma $o$ nu este atestată în aceste texte.
} 
Weinreich, 1953, p. 18), în care, din motive încă greu de înțeles ${ }^{2}$, forma $o$ tinde să se specializeze pentru contextele în care apar și alte clitice, iar formele literare sînt preferate în absența altor clitice.

\section{Bibliografie}

\section{A. Corpus}

A.1620 = Alexandria, în Zgraon, Fl. (ed.), Cele mai vechi cărți populare in literatura română, vol. 11, Fundația Națională pentru Știință și Artă, București, 2006.

ALR I = S. Pop, Atlasul lingvistic român, vol. I, coord. S. Pusccariu, partea a II-a, Otto Harrassowitz, Sibiu/Leipzig, 1942.

ALR s.n. V = Atlasul lingvistic român, serie nouă, vol. V, Editura Academiei, București, 1966.

ALR s.n. VI = Atlasul lingvistic român, serie nouă, vol. VI, Editura Academiei, București, 1969.

DB = Bianu, I. (1907). Documente românești, București.

DIR A II = Documente privind istoria României. Veacul XVII. A. Moldova, vol. II (1606-1610), Editura Academiei, București, 1953.

DR = Caragiu Marioțeanu, M., Giosu, Ș., Ionescu-Ruxăndoiu, L. \& Todoran, R. (1977). Dialectologie română, Editura Didactică și Pedagogică, București.

DRH A XIX = Documenta Romania Historica. A. Moldova, vol. XIX (1626-1628), Editura Academiei, București, 1969.

DRH A XXI = Documenta Romania Historica. A. Moldova, vol. XXI (1632-1633), Editura Academiei, București, 1971.

DRH B XXIII = Documenta Romania Historica. B. Țara Românească, vol. XXIII (1630-1632), Editura Academiei, București, 1969.

$\mathrm{IM}=$ Bîrlea, I. (1909). Însemnări din bisericile Maramuręsului, București.

NALR = Duminstrăcel, S. (1995). Noul atlas lingvistic român pe regiuni. Moldova şi Bucovina, I, Partea a 2-a, Editura Academiei Române, Iași.

Po.1582 = Pamfil, V. (ed.) (1968). Palia de la Orăștie, Editura Academiei, București.

Prav.1581 = Rizescu, I. (ed.) (1971). Pravila ritorului Lucaci, Editura Academiei, București, p. 161-183.

ş, 1644 = Mazilu, I. (ed.) (2012). Şeapte taine a besearecii, Iaşi, 1644, Editura Universităţii „Alexandru Ioan Cuza”, Iași, p. 173259.

$\mathrm{TD}=$ Petrovici, E. (1943). Texte dialectale. Suplement la Atlasul lingvistic român II, Muzeul Limbii Române/Otto Harrassowitz, Sibiu/Leipzig.

\section{B. Referințe}

Botez, M. (2016). O analiză morfologică a auxiliarelor de perfect compus și de viitor în graiul din Moldova, comunicare la BEST Letters Colloquia, ediția a III-a, București, 28-29 octombrie.

Caragiu Marioțeanu, M., Giosu, Șt., Ionescu-Ruxăndoiu, L. \& Todoran, R. (1977). Dialectologie română, Editura Didactică și Pedagogică, București.

Coteanu, I. (1961). Elemente de dialectologie a limbii române, Editura Științifică, București.

Dragomirescu, A. (2012). Verbul [secolul al XIX-lea], în Chivu, Gh., Pană Dindelegan, G., Dragomirescu, A., Nedelcu, I. \& Nicula, I. (eds) Studii de istorie a limbii române. Morfosintaxa românei literare in secolele al XIX-lea - al XX-lea, Editura Academiei Române, București, 2012 (ediție revizuită, 2015), p. 185-222.

Frâncu, C. (1969). Formele de persoana a III-a ale auxiliarului de la perfectul compus. Privire istorică, în „Studii și cercetări lingvistice, vol. XX, nr. 3, p. 299-318.

Gheție, I. (1975). Baza dialectală a românei literare, Editura Academiei, București.

Ledgeway, A. (2017). Parallels in Clausal and Nominal Structures: Romanian Clitic Placement, în Dragomirescu, A., Nicolae, A., Nicula Paraschiv, I. \& Pană Dindelegan, G. (eds), Romance Syntax. Comparative and Diachronic Perspectives, Cambridge Scholars Publishing, Newcastle (sub tipar).

TDR = Tratat de dialectologie românească, Editura Scrisul Românesc, Craiova, 1984.

Van Coetsem, F. (1992). The Interaction between Dialect and Standard Language, and the Question of Language Internationalization, în Van Leuvensteijn, J. \& Berns, J. (eds), Dialect and Standard Language. Dialekt und Standardsprache in the English, Dutch, German, and Norwegian Language Areas, Royal Netherlands Academy of Arts and Sciences, Amsterdam/Oxford/New York/Tokyo, p. 15-70, [online].

Weinreich, U. (1953). Languages in Contact. Findings and Problems, Mouton, The Hague, Crossref.

Zamfir, D.-M. (2007). Morfologia verbului in dacoromâna veche (secolele al XVI-lea - al XVII-lea), vol. II, Editura Academiei Române, București.

\footnotetext{
${ }^{2} \mathrm{Nu}$ am putut identifica un context fonetic precis care să favorizeze folosirea formei $o$. Pentru concluzii similare legate de topica cliticului pronominal $o$, vezi Ledgeway (2017).
} 